\title{
Cyclin-Dependent Kinase-Like 5
}

National Cancer Institute

\section{Source}

National Cancer Institute. Cyclin-Dependent Kinase-Like 5. NCI Thesaurus. Code C75306.

Cyclin-dependent kinase-like 5 (1030 aa, $\sim 116 \mathrm{kDa}$ ) is encoded by the human CDKL5

gene. This protein plays a role in protein phosphorylation. 